\title{
Influential factors in the management of pulmonary tuberculosis therapy by nurses in health centers
}

\author{
Raditya Kurniawan Djoar ${ }^{1 *}$; Anastasia Putu Martha Anggarani ${ }^{2}$ \\ ${ }^{\text {1*); } 2}$ STIKES Katolik St.Vincentius a Paulo Surabaya
}

\section{ARTICLE INFO}

Article history:

Received June 03, 2019

Revised August 13, 2019

Accepted August 24, 2019

\section{Keyword:}

Nurse's role

Tuberculosis

Task

Guidance

*) corresponding author

Lecturere or Nursing Program

STIKES Katolik St. Vincentius a Paulo

Surabaya

Jl. Jambi 12-18, 031-5612220

Email: radit stikvinct@yahoo.com

DOI: https://doi.org/10.30604/jika.v4i2.205

\section{A B S T R A C T}

Tuberculosis (TB) often attacks individuals who live in urban areas and have low socioeconomic levels in tropical countries such as Indonesia. Prevention efforts have been carried out by providing $B C G$ immunization to toddlers and campaigns regarding clean and healthy living. with this effort, Indonesia has not been free from this disease. The purpose of this research was to identify factors that influence the role of nurses in the management of pulmonary TB therapy. This research is a cross sectional research and the statistical test used is Pearson correlation followed by multiple linear tests with a significance level $=0.05$. Statistical test results show that there is a relationship between daily tasks and guidance of senior nurses / leaders with the role of nurses in the management of TB therapy (alpha 0,000) and multiple linear statistical tests indicate there is an influence of senior nurse / leader guidance on the implementation of the nurse's role in managing TB therapy. When seen from the results of the $F$ value obtained simultaneously there is an influence between daily tasks and guidance of senior nurses $/$ leaders of $55.3 \%$ on the implementation of the nurse's role in the management of TB therapy. Based on the results of the research, it can be used by the health center in particular to succeed in the management of TB therapy, can do a combination in the assignment of nurses where they can be assigned to the pulmonary TB service by getting guidance from senior nurses / unit leaders.

This is an open access article under the CC-BY-SA license. 


\section{INTRODUCTION}

Tuberculosis is an infectious disease that develops in many tropical countries, and often attacks individuals who live in urban areas and have a low socioeconomic level (Kunoli, 2013) (Ministry of Health of the Republic of Indonesia, 2018). This disease is caused by Mycrobacterium Tuberculosis (Rafflesia, 2014). Indonesia with the largest tropical region in the world has not been free from TB cases, where in several cases it was found that this disease attacks all age groups both women and men, and began to spread not only to low socio-economic groups only (Kunoli, 2013). Some early prevention efforts have been carried out, namely by BCG immunization to children under five, as well as campaigns to live clean and healthy. Nevertheless, Indonesia has not been free from this disease (Widjaya, 2009).

Based on the reference data for achieving Millennium Development Goals (MDGs) targets in Indonesia, pulmonary TB is one of the targets where pulmonary TB is included in point 6 of the MDGs after HIV / AIDS and malaria. In 2015 the target to be achieved is to halve the prevalence of pulmonary TB and deaths due to pulmonary TB (Widyanto, 2013). However, the latest data in 2015 found that the number of tuberculosis cases increased compared to all tuberculosis cases found in 2014 (Ministry of Health of the Republic of Indonesia, 2015). Of course this should be of particular concern to state administrators, especially those engaged in health.

Data on Indonesia's health profile shows that TB still needs serious attention. Based on data from Indonesia's Health Profile in 2015 Indonesia ranks third after India and China with approximately 583,000 people (Naga, 2012). In 2016, based on Indonesian health profile data, there were 156,723 new cases of tuberculosis, with East Java province ranking second with 21,606 new cases of pulmonary TB, with the city of Surabaya occupying the highest position with the discovery of 3569 cases. The success rate of treatment of tuberculosis patients in Indonesia in 2016 was $85.7 \%$ with a cure rate reaching $80.6 \%$ (Ministry of Health of the Republic of Indonesia, 2015). This cure rate is caused by several factors namely the patient, PMO, and virulence and the number of germs (Kunoli, 2013).

Based on these data shows that there are still some obstacles in achieving success in TB treatment, one of which is related to the role of HR especially nurses in health centers to carry out tasks, especially in maintaining TB patient compliance in treatment management. The results of previous studies conducted at one of the health centers in the city of Surabaya showed that there was a positive relationship between the role of nurses and the level of compliance of patients with pulmonary TB in the management of therapy (Puspita, Kurnia, \& Mela, 2017). The research illustrates that the role of nurses, especially in the management of TB therapy, is in the range of behaviors that sometimes perform roles followed by a large proportion of moderate adherence. So when viewed from the results of the replace, the optimization of the role still needs to be reviewed so that it is more optimal because to minimize the impact of non-compliance, one effort that can be done is to maximize the role of health practitioners including the role of nurses (WHO, 2014)

However, based on previous research conducted on puskesmas nurses in rural and urban areas, there are several factors that can influence the management of the nurse's role. These factors include daily tasks, workplace environment, participation in training, and guidance of senior nurses / leaders (Djoar, 2016).

The role of nurses in TB management consists of several roles, namely as care givers, patient advocates, educators and counselors (Maria et al., 2012) (Novitasari, 2016). In this case the nurse's role as a provider of care, nurses must have a friendly 
and friendly attitude, involve the family and provide support in the supervision of taking medication, giving reminder letters, reminder phone calls and home visits to patients who stop. As a nurse educator can provide counseling about adherence, drug use, drug side effects, dosage, duration of administration and characteristics of appropriate treatment (Peu, 2012), ensuring that information related to tuberculosis and the need to undergo treatment is conveyed. As a nurse advocate can optimize collaboration between various services (WHO, 2014). As an intervention counselor that nurses can do is counseling if psychological problems are obstacles to medication adherence (Loriana, Parellangi, \& Siswoyo, 2013) (El-aal \& Mostafa, 2015).

Often this role cannot be carried out optimally by nurses so that it has an impact on the failure of TB treatment, management, and so far no definitive data have been found related to what factors affect the implementation of this role so it is necessary to identify what factors influence TB treatment management in particular to nurses at the puskesmas.

\section{METHOD}

The replace design uses cross-sectional. In this replace, researchers will look for the influence of independent variables, namely the environment, tasks, training, and guidance with the dependent variable, namely the role of nurses. The target of this research is 33 nurses in the working area of Surabaya city health center who are willing to be respondents and at least a D3 nursing education. The sampling technique uses consecutive sampling. The data collection was carried out starting from the researchers asking for a research permit from the Chairperson of STIKES Catholic St. Vincentius A Paulo Surabaya, after obtaining a research permit, and Surabaya City Health Office. After obtaining permission, the researcher submits a research approval letter to the Puskesmas. After obtaining approval from the Puskesmas the researchers collected information data. In this replace researchers used a research instrument in the form of a questionnaire. Questionnaire is a data collection technique where participants / respondents fill in questions or statements then after being filled out completely returns to the researcher. The questionnaire used in the replace was a nurse role questionnaire that used a Likert scale very often 4 , often a value of 3 , sometimes 2 , never a value 1 . The nurse role questionnaire consisted of 24 statements in which statements about the nurse's role as the provider of nursing care to the items $1,2,3,4,5,6,7,8,9,10,11,12,13$, roles as educators and advocates on items $14,15,16,17,18$, and roles as counselors on item $19,20,21,22,23,24$.

The instrument validation of the nurses' role questionnaire test results from 24 statements was declared valid with a correlation value of 1 means> 1, in this replace using a computerized system to perform the reliability test. To see the results can be seen in Cronbach Alpha, the nurse role questionnaire results obtained 0.976 , which means $>0.7$.

After the data are collected, a descriptive analysis is performed, the statistical test using Pearson correlation is continued with multiple linear tests with a significance level of $\alpha=0.05$.

\section{RESULTS AND DISCUSSION}

Based on the results of statistical tests show that there is an influence of the guidance of senior nurses / leaders on the implementation of the role of nurses in the management of TB therapy, and when seen from the results of the $\mathrm{F}$ value found that simultaneously there is an influence between daily tasks and guidance of senior nurses / leaders by $55.3 \%$ on the implementation the role of nurses in the management of TB therapy. 
Table 1

Multiple Regression Statistics Test Results

\begin{tabular}{lccccc}
\hline \multicolumn{1}{c}{ Multiple Regression } & t & Sig & F & Sig & R square \\
\hline Daily Task & 1.051 & 0.300 & 22.266 & 0.000 & 0.553 \\
Guidance for senior nurses/leaders & 2.528 & 0.016 & & & \\
\hline
\end{tabular}

Based on statistical tests of the four independent variables, only two variables, namely daily tasks and guidance of senior nurses / leaders related to the role of nurses in the management of TB therapy.

According to previous research (Djoar, 2016) the varying division of tasks will also enhance the implementation of roles by nurses, in addition to the guidance of the head of the health center and from the leadership of the nurse. The purpose of the guidance is to ensure that the implementation of various activities is planned to run well so that it truly displays roles that are in line with the task (Anggraeni \& Pujiyanto, 2014). There is a correlation between the theory and the fact that the division of tasks in accordance with one's ability will be able to optimize the implementation of the role for nurses. This is supported by the data also that of the 28 respondents who carry out the role above the mean states they have done the task in the management of TB therapy in the range sometimes - sometimes up to very often.

Based on multiple regression linear statistical tests by comparing $t$ arithmetic with ttable, it was found that the guidance of senior nurses / puskesmas leaders influenced the implementation of the nurse's role in the management of TB therapy. The guidance provides an opportunity for everyone to get a full explanation of what is being done, including in the implementation of the nurse's role (Carlsson, Johansson, Eale, \& Kaboru, 2015). There is a match between theory and the fact that guidance from seniors / leaders can have an influence on the implementation of the nurse's role, this can occur because when someone who gets guidance, especially from a senior colleague or leader, there will be a sense of trust so that they will follow the advice and recommendations of the process guidance that has been implemented.

When seen from the results of the $F$ test it was found that simultaneous daily assignment accompanied by guidance by senior / leadership on the management of TB therapy had an influence on the implementation of the nurse's role in the management of TB therapy. This is consistent with the theory that if these two factors are given to nurses in charge of serving TB therapy, it will greatly help the nurse to be able to carry out their roles and duties so that the healing process of patients will be more optimal, in addition it is necessary to provide appropriate training to carry out the role as nurses in dealing with problems in tuberculosis sufferers, because based on previous research obtained data that participation in training is related to the ability of nurses in carrying out their roles, the more participating in training specifically related to tuberculosis will increase the abilities and skills of nurses (Djoar, 2016).

On the other hand when viewed from the $\mathrm{R}$ square results it was found that simultaneously these two factors had an effect of $55.3 \%$ on the implementation of the nurse's role in the management of TB therapy. This can be made possible because there are still other factors that may need to be studied in more depth so that any factors that have a big influence on the role of nurses in the management of pulmonary TB therapy in the health center can be identified.

\section{CONCLUSIONS AND SUGGESTIONS}

Based on the results of the replace indicate that senior guidance / leadership is the most 
influential factor on the role of nurses in the management of pulmonary TB therapy.

On the other hand, if done simultaneously, daily tasks and senior / leadership guidance are factors that have an effect of $55.3 \%$ on the role of nurses in the management of pulmonary TB therapy

In accordance with the results of the replace can be used by HR in the health center in particular to succeed in the management of TB therapy can do a combination in the assignment of a nurse where they can be assigned to the pulmonary TB service by getting guidance from senior nurses and unit leaders.

Whereas for further researchers need to be followed up on the identification of other

\section{REFERENCES}

Anggraeni, N., \& Pujiyanto. (2014). Analisis Manajemen Program TB Paru di Puskesmas Kecamatan Kemayoran Jakarta Pusat Tahun 2014. Retrieved from lib.ui.ac.id/naskahringkas/201606/S56120-Nuri Anggraeni

Carlsson, M., Johansson, S., Eale, R. B., \& Kaboru, B. B. (2015). Nurses ' Roles and Experiences with Enhancing Adherence to Tuberculosis Treatment among Patients in Burundi: A Qualitative Study. Tuberculosis Research and Treatment, 2014. https://doi.org/http://dx.doi.org/10.115 5/2014/984218

Djoar, R. K. (2016). Public health nursing in Indonesia: difference in roles and functions in rural and urban centers. International Journal of Research in Medical Science, 4(1), 219-224. https://doi.org/http://dx.doi.org/10.182 03/2320-6012.ijrms20160034

El-aal, E. M. A., \& Mostafa, M. M. (2015). Nursing Intervention Program for Tuberculosis Patients by Using Epidemiological Model. American factors that influence the implementation of the role because only $55.3 \%$ of the combination of daily tasks and guidance from seniors / leaders influence the implementation of the nurse's role in the management of pulmonary tuberculosis therapy, there are still around $44.7 \%$ influence beyond that, so that when these other factors have been identified, they can be used to succeed in TB management through the role of nurses.

\section{ACKNOWLEDGEMENT}

The resarcher would like to thank the entire academic community of STIKES Catholic St. Vincentius a Paulo Surabaya, which has provided material and non-material support to the research process.

Journal of Nursing Science, 4(3), 119126.

https://doi.org/10.11648/j.ajns.201504 03.21

Kementrian kesehatan Republik Indonesia. (2018). Pusat Data dan Informasi Kementrian Kesehatan RI. Jakarta. Retrieved from www.depkes.go.id/download.php?file= download/pusdatin/...pdf\%0A\%0A

Kementrian Kesehatan Republik Indonesia. (2015). Profil Kesehatan Indonesia 2015. Retrieved from http://www.depkes.go.id/resources/do wnload/pusdatin/profil-kesehatanindonesia/profil-kesehatan-Indonesia2015.pdf

Kunoli. (2013). Pengantar Ilmu Epidemiologi Penyakit Menular: Untuk Mahasiswa Kesehatan Masyarakat (Cet 1). Jakarta: Trans Info Media. Retrieved from http://ucs.sulsellib.net//index.php?p=sh ow_detail\&id=41999 
Loriana, R., Parellangi, \& Siswoyo. (2013). Efek konseling terhadap pengetahuan, sikap dan kepatuhan berobat penderita tuberkulosis paru. Jurnal Husada Mahakam, III(6), 281-287. Retrieved from http://husadamahakam.poltekkeskaltim.ac.id/ojs/index.php/Home/articl e/view/47/54

Maria, B., Firmino, E., Tavares, M. G., Tiemi, A., Rubia, A., Paula, L. De, ... Scatena, C. (2012). Nursing Approach to the Control of Tuberculosis: Scientific Publications ( 2002-2011). International Journal of Research in Nursing, 3(2), 30-37. https://doi.org/10.3844/ijrnsp.2012.30. 37

Naga, S. S. (2012). Buku Panduan Lengkap Ilmu Penyakit Dalam. Jogjakarta: Dive Press. Retrieved from http://ucs.sulsellib.net//index.php?p=sh ow_detail\&id=12643

Novitasari. (2016). Gambaran tentang peran perawat pada perawatan pasien $\mathrm{TB}$ Paru di ruang rawat inap di balai besar kesehatan masyarakat Surakarta. Retrieved from http://digilib.stikeskusumahusada.ac.id /files/disk1/32/01-gdl-novitasari-15931-publikas-i.pdf

Peu, M. D. (2012). Role of community nurses in the prevention of tuberculosis in the Tshwane Health District of Gauteng. Curationis, (May 2014). https://doi.org/10.4102/curationis.v35i 1.47

Puspita, D., Kurnia, S., \& Mela, C. (2017). Penyakit TB Paru diwilayah Kerja Puskesmas Getasan, 13(2), 5-11. Retrieved from http://ejournal.poltekkessmg.ac.id/ojs/index.php/link/article/vie wFile/2840/569

Rafflesia, U. (2014). Model Penyebaran Penyakit Tuberkulosis ( TBC ). Jurnal Gradien, 10(2), 983-986. Retrieved from https://ejournal.unib.ac.id/index.php/gr adien/article/viewFile/225/197

WHO. (2014). Tuberculosis Care (3rd ed.). WHO. Retrieved from https://www.who.int/tb/publications/IS TC_3rdEd.pdf

Widjaya, R. (2009). Penyakit Kronis, Tindakan, Pencegahan dan Pengobatan Secara Medis maupun Tradisional. Jakarta: Bee Media Indonesia.

Widyanto, F. \& T. C. (2013). Trend Disease Trend Penyakit Saat Ini. Jakarta: CV TRANS INFO MEDIA. Retrieved from http://onesearch.id/Record/IOS4633.sli ms-519 